\title{
SOLAR FED PMSM DRIVEN WATER PUMPING SYSTEM USING SEPIC CONVERTER
}

\author{
Saneep K \\ Department of EEE \\ NSS College of Engineering \\ Palakkad, Kerala, India \\ Dr. Leesha Paul \\ Department of EEE \\ NSS College of Engineering \\ Palakkad, Kerala, India
}

\author{
Dr. Vasanthi V \\ Department of EEE \\ NSS College of Engineering \\ Palakkad, Kerala, India \\ Dr. Priya G Das \\ Department of EEE \\ NSS College of Engineering \\ Palakkad, Kerala, India
}

\begin{abstract}
This paper deals with the application of a single ended primary inductor converter (SEPIC) in solar photovoltaic (SPV) array fed water pumping system. A permanent magnet synchronous motor (PMSM) motor is employed to drive a centrifugal pump coupled to its shaft. A vector control PMSM motor is achieved by controlling the SEPIC through the incremental conductance maximum power point tracking (INC-MPPT) algorithm. The SEPIC possesses the merits of non-inverting polarity output voltage, simple gate-drive circuit and low input current pulsation. It can increase or decrease it's output voltage according to duty ratio. This property provides the flexibility of optimizing the operating point of the SPV array at any voltage level. The outputs of the proposed system is verified through simulated results using MATLAB/ Simulink environment.
\end{abstract}

\section{Keywords - PMSM, Solar, SEPIC Converter, Water Pumping}

\section{INTRODUCTION}

Flourishing industries and population explosion are the main causes of increasing demand of electrical energy and depletion of conventional sources. The consequences are quite evident in the form of abrupt climate change and global warming. The ultimate remedy of these problems is sought to be renewable power generation [1-3]. Solar energy is the best available renewable source of energy especially for driving motors for water pumping [5].

The development in the semiconductor technology provides the large increase in the generation of solar power. The basic building block of PV power generation system is the PV cell. PV cells are grouped to form PV arrays. Modelling of PV array in single diode model is explained in [6] and two-diode model is reported in [7], where one more diode is used to represent the recombination of carriers. For the maximum power point tracking (MPPT) control, a DC- DC converter is used, whereas the DC-link voltage is regulated by three-phase voltage- source inverter (VSI) [8].

The standalone SPV system gives a promising solution with low maintenance and low-cost solicitation for water pumping system in remote areas. MPPT conversion system is used to efficiently use the SPV system. Generally, the dc-dc conversion- system is a dc-dc converter of which duty cycle is controlled in a way such that SPV system operates at maximum power. The MPPT techniques that are prominent in tracking MPP are open circuit-voltage method, short circuitcurrent method, perturb \& observe method, incrementalconductance method, neural network \& fuzzy techniques. Choosing a befitting DC-DC converter plays a crucial role for optimum performance of the system. a non- isolated DC to DC converter gives optimum performance for low voltage conversion than isolated converter by exempting conduction losses that occur during energy transfer between primary and secondary windings. Due to its output gain flexibility, single ended primary inductor converter (SEPIC) acts as a buck boost DC-DC converter providing non-inverting polarity output voltage, where it changes its output voltage according to its duty cycle. Unlike the DC-DC buck and boost converter, the SEPIC has an unbounded maximum power point tracking (MPPT) region. Because of its non- inverting polarity output voltage, unlike the buck-boost and a Cuk DC-DC converter, the use of either splitting power supply or optocoupler and associated circuit for negative voltage feedback sensing, which added complexity and slowed down the response of the system, is eliminated. The inductor at the input of the SEPIC reduces the input current pulsation resulting in a high precision of MPPT It also provides unbounded MPPT region. For solar pumping systems below $5 \mathrm{~kW}$ DC motors are generally used. for high power systems PMSM motor gives 
better performance than induction motors and DC motors as they provide optimal efficiency, high torque to size ratio and dynamic response along with system ruggedness reliability, maintenance free and helps in optimal sizing of SPV array and voltage source inverter (VSI).

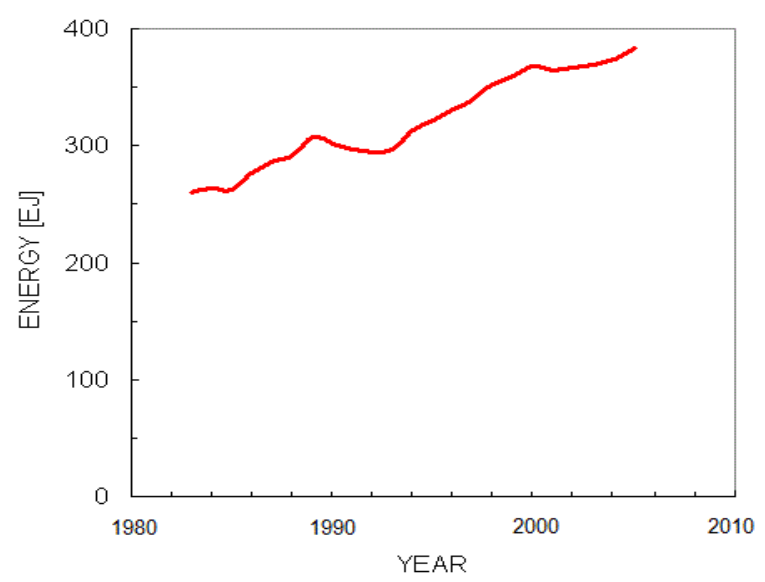

Fig. 1. World primary energy consumption in EJ (x1018 joule)

The world energy requirement is ever growing particularly since the last few centuries. It is expected to grow further in the future. There are two main drivers for the increase in the energy demand:

Growth in the world's population.

The techno-economic growth of countries, particularly developing countries.

As both of these grow, the energy demand grows proportionally.

The total energy consumed in the form of coal, gas and oil, nuclear, hydro and renewable energy source is known as primary energy. The primary energy consumption was at $488 * 1018 \mathrm{~J}$ or 488 exajoule (EJ) in 2005 . It had grown from $385 \mathrm{EJ}$ at over $2.4 \%$ of compound annual growth rate (CAGR) since 1995. The future growth rate of energy demand is expected to be in the same range if not higher.

A SPV water pumping system consists of a PV array, a converter surface mounted/submersible/floating motor pump set, and electronics. The PV Array is mounted on a suitable structure with a provision of manual or automatic tracking. Water is pumped during day and stored in tanks, for use during day time, night or under cloudy conditions. The water tank acts as storage and generally battery is not used for storage of PV electricity; however, for specific reliable requirements it can be used. The steady fall in prices of solar photovoltaic (PV) panels have resulted in making solar pumping economically viable for an increasingly wide range of applications. Direct-coupled DC solar pumps are simple and reliable but cannot operate at maximum power point of PV generator as the solar radiation varies during the day from morning till evening. However, adding a maximum power point tracker (MPPT) and controls/protections improve the performance of a PV pump.

PV water pumping systems have shown significant advancements in the last decade. The first generation PV pumping systems used centrifugal pumps usually driven by DC motors and variable frequency alternating current (AC) motors, with proven long-term reliability and hydraulic efficiency varying from $25 \%$ to $35 \%$. The second generation PV pumping systems use positive displacement pumps, progressing cavity pumps or diaphragm pumps, generally characterized by low PV input power requirements, low capital cost and high hydraulic efficiencies of even $70 \%$. The current solar pumping technology uses electronic systems, which have further increased the output power, performance of the system and overall efficiency of the system. The controller provides inputs for monitoring storage tank levels, controlling the pump speed and uses maximum power point tracking technology to optimize the water. Advancement has taken place in the tracking mechanism of PV arrays from manual tracking to dual axis automatic tracking systems by microcontroller programming. Tracking the sun reduces the physical size of PV panel area required for a given output, improves power yield, overall efficiency of the system and return on investment. Tracking of a solar pumping system extends the time for peak water yield. The solar pumps available in the market can lift water from $5 \mathrm{~m}$ to more than $200 \mathrm{~m}$ with outputs of up to $250 \mathrm{~m}^{3} /$ day. For the past 15 years significant improvement has been done in helical motor pumps (positive displacement pumps) which are submersible and last for many years and are powered by similar motors as used for centrifugal pumps. The steady increase in cost of diesel and gasoline prices over the years and decrease in PV system costs make PV pumping attractive from financial perspective also. Furthermore, crystalline PV modules with high efficiencies of $16.84-21.5 \%$ are available in the International market in 2014. In the following section, an overview of solar water pumping technology is presented.

For an indication, the share of primary energy sources in total world energy requirement is shown in figure (The data are for 2002). In the last 25 years between 1980 and 2005, there has been a significant fuel shift from petroleum to dry natural gas. The share of petroleum has fallen from $46 \%$ in 1980 to about $36 \%$ in 2005 . There has been significant increase in the share of natural gas from $19 \%$ to close to $24 \%$ and in nuclear electricity from $2.67 \%$ in 1980 to about $6 \%$ in 2005 . Energy from fossil fuels grew fastest in coal (3.3\% CAGR) followed by natural gas (2.8\% CAGR) between 1995 and 2005. Growth rates have, however, been lower in hydroelectric power since 1995 registering only about $1.1 .3 \%$ CAGR, while growth in petroleum consumption and nuclear energy was higher at about $1.7 \%$ CAGR in the same period. 


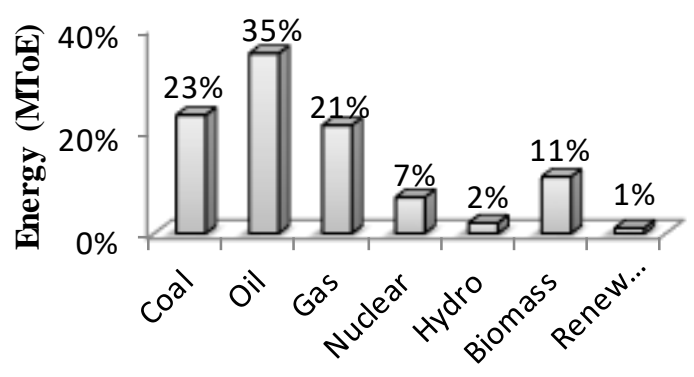

Fig. 2. Share of primary energy sources in world's total energy supply

There is also a significant growth in the consumption of renewable energy sources. The growth rates have been the highest for renewable energy technology at about 7\% CAGR, but its share has been minimal under $1 \%$. The situation, as of today, remains nearly the same. However, it should be noticed that there are significant growth in all renewable energy technologies, which will lead to higher contribution in the world's energy requirements.

The efficiency of PV technology used in PV generator has also a great influence on the performance. Besides the degradation of PV panels is one of the important parameters, which affect the performance of a solar pump. The performance of solar water pumping system depends on the following parameters:

Solar radiation availability at the location;

Total Dynamic Head (TDH): Sum of suction head (height from suction point till pump), discharge head (height from pump to storage inlet) and frictional losses;

Flow rate of water.

Total quantity of water requirement; and

Hydraulic energy: potential energy required in raising the water to discharge level.

\section{CONFIGURATION OF PROPOSED SYSTEM}

The proposed system under study is shown in Figure. The system consists of the SPV array followed by the SEPIC, which feeds the VSI, supplying the PMSM motor coupled to a centrifugal type of water pump. MPPT algorithm generates switching pulse for the switch of SEPIC whereas the sine pulse width modulation generates the switching sequence for the switches of the VSI.

Fig. 3. Block diagram for proposed system

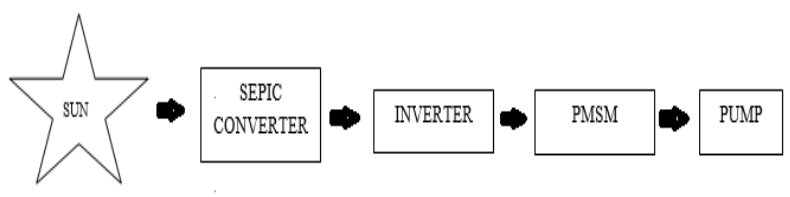

The proposed system under study is shown in Figure. The system consists of the SPV array followed by the SEPIC which feeds the VSI, supplying the PMSM motor coupled to a centrifugal type of water pump. MPPT algorithm generates switching pulse for the switch of SEPIC whereas the sine pulse width modulation generates the switching sequence for the switches of the VSI.

Schematic diagram for the stand-alone solar PV based PMSM drive for water-pumping system is shown. The proposed system consists of solar PV panel, a boost converter, a three phase VSI (Voltage Source Inverter) and a PMSM coupled with a centrifugal water pump. A PV or solar cell is the basic building block of a PV system. An individual PV cell is usually quite small, typically producing about 1 or $2 \mathrm{~W}$ of power. To increase the power output of PV cells, these cells are connected in series and parallel to assemble larger unit called PV module. The PV array is connected to the DC-toDC boost converter to increase the output voltage level. An IGBT (Insulated Gate Bipolar Transistor) based VSI is used for DC to AC conversion and connected to the PMSM drive. The constant DC voltage is converted to the AC output using a VSI.

\section{Design of The Proposed System}

The proposed system comprises a solar PV array, a SEPIC, a VSI, a PMSM motor and a centrifugal water pump. The solar PV array, the SEPIC and the centrifugal pump are designed as per the requirement of the proposed system. Power ratings of the PMSM motor and the centrifugal pump are selected as $2.2 \mathrm{~kW}$ and $2 \mathrm{~kW}$ respectively. Based on these selected ratings.

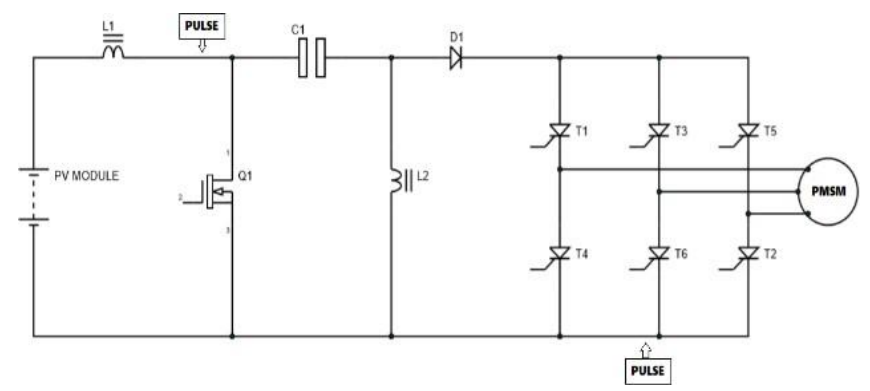

Fig. 4. Circuit Diagram

\section{A. Design of Solar PV Array -}

The SPV array is designed for Pmpp $=2.73 \mathrm{~kW}$ peak power capacity. First of all, a PV module of 36 cells connected in series is designed to produce an open circuit voltage of 13.32 $\mathrm{V}$ and short circuit current of $4 \mathrm{~A}$. It is reported that the peak power generally occurs between $71 \%$ and $78 \%$ of open circuit voltage and between $78 \%$ and $92 \%$ of short circuit current [9]. 
Hence, the voltage of a module at MPP, $\mathrm{Vm}=0.78 * 13.32=$ $10.39 \mathrm{~V}$ and the current of a module at MPP, $\mathrm{Im}=0.8 * 4=3.2$ A. Voltage of the SPV array at MPP is considered as, Vmpp = 114.4 V in view of the DC link voltage of the VSI, Vdc which is the output voltage of the SEPIC and the input voltage of the inverter.

Short circuit current, $\mathrm{I}_{\mathrm{SC}}$ : This is the maximum current that flows in a solar cell when its terminals at $\mathrm{P}$ side and $\mathrm{N}$ side are shorted with each other, i.e., $\mathrm{V}=0$.

When we put $\mathrm{V}=0$ in

$$
I_{\text {total }}=I_{O}\left(e^{\frac{\mathscr{V} V}{\mathrm{~V} T}}-1\right)-I_{L}
$$

We will get $\mathrm{I}_{\mathrm{SC}}=-\mathrm{I}_{\mathrm{L}}$. Thus short circuit current is nothing but the light generated current. The short circuit current is usually represented in terms of current density and current per unit area, in terms of $\mathrm{ma} / \mathrm{cm} 2$.

Open circuit voltage $\mathrm{V}_{\mathrm{OC}}$ : As the name suggests, it is the maximum voltage generated across the terminals of a solar cell when they are kept open, i.e., $\mathrm{I}=0$. Putting this condition in the above equation, the following expression for open circuit voltage is obtained,

$$
V_{O C}=\frac{k T}{q} \operatorname{Ln}\left(\frac{I_{L}}{I_{Q}}+1\right)
$$

Thus open circuit voltage depends on the light generated current and reverse saturation current. The $\mathrm{V}_{\text {OC }}$ is given in terms of $\mathrm{mV}$ or $\mathrm{V}$.

Fill factor, FF: it is the ratio of maximum power $\mathrm{Pm}=\mathrm{Vm} * \mathrm{Im}$, that can be extracted from a solar cell to the ideal power $\mathrm{P}_{\mathrm{O}}=$ $\mathrm{V}_{\mathrm{OC}} * \mathrm{I}_{\mathrm{SC}}$. Thus,

$$
F F=\frac{V_{T R} I_{T R}}{V_{D E} I_{S E}}
$$

FF represents the squareness of the solar cell I-V curve. It is represented in terms of percentage.

Efficiency, $\eta$ : It is defined as the ratio of the power output to power input. The power output is the maximum power point $\mathrm{P}_{\mathrm{m}}$ of a solar cell; the input power is the power of solar radiation, $\mathrm{P}_{\mathrm{rad}}$. According to the international standard for characterization of solar cells, $\mathrm{P}_{\mathrm{rad}}=100 \mathrm{mw} / \mathrm{cm} 2$ or $1000 \mathrm{~W} / \mathrm{m} 2$.

$$
\eta=\frac{P_{m}}{P_{\mathrm{rad}}}
$$

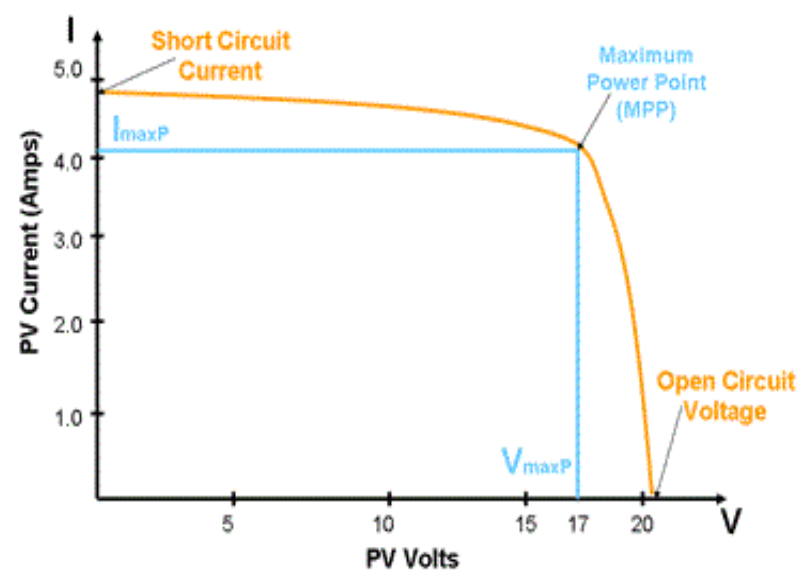

Fig. 5. Typical plot of a solar cell I-V curve and its parameters

The current of the SPV array at MPP,

$$
\begin{aligned}
\text { Impp } & =\mathrm{Pmpp} / \mathrm{Vmpp} \\
& =2730 / 114.4=23.86 \mathrm{~A} .
\end{aligned}
$$

Numbers of modules required to connect in series are as,

$$
\begin{aligned}
\mathrm{Ns} & =\mathrm{Vmpp} / \mathrm{Vm} \\
& =114.4 / 10.39=11
\end{aligned}
$$

Numbers of modules required to connect in parallel are as,

$$
\begin{aligned}
\mathrm{Np} & =\mathrm{Impp} / \mathrm{Im} \\
& =23.86 / 3.2=7.46 \approx 8
\end{aligned}
$$

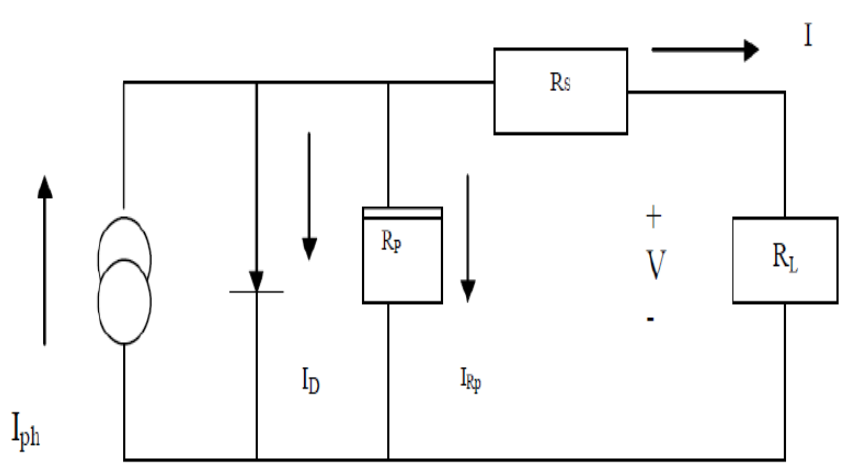

Fig. 6. Solar cell model

Solar cells or PV cells are the basic components of PV module and it is the element in charge of transforming the sun rays or photons directly into electric power. An ideal PV is modeled by a current source in parallel with a diode [5]. However no solar cell is ideal and thereby shunt and series resistances are 
added to the model as shown in the PV cell diagram above. Rs is the intrinsic series resistance whose value is very small. Rp is the equivalent shunt resistance which has a very high value Applying Kirchhoff's current law to the node where Iph, diode, $\mathrm{Rp}$ and Rs meet, we get

$$
I_{\mathrm{ph}}=I_{D}+I_{R_{p}}+I
$$

We get the following equation for the photovoltaic current:

$$
I=I_{\mathrm{ph}}-I_{D}-I_{R_{p}}
$$

where, Iph is the insolation current, I is the cell current, ID is the diode current and IRp is the current through the parallel resistor

The current source Iph represents the cell photo current; $\mathrm{Rj}$ is used to represent the non-linear impedance of the $\mathrm{p}-\mathrm{n}$ junction; Rsh and Rs are used to represent the intrinsic series and shunt resistance of the cell respectively. Usually the value of Rsh is very large and that of Rs is very small, hence they may be neglected to simplify the analysis. PV cells are grouped in larger units called PV modules which are further interconnected in series-parallel configuration to form PV arrays or PV generators. The PV mathematical model used to simplify our PV array is represented by the equation:

$$
I=n_{p} I_{p h}-n_{p} I_{r s}\left[\exp \left(\frac{q}{n T A} * \frac{V}{n_{r}}\right)-1\right]
$$

where I is the PV array output current; V is the PV array output voltage; ns is the number of cells in series and $n p$ is the number of cells in parallel; $\mathrm{q}$ is the charge of an electron; $\mathrm{K}$ is the Boltzmann's constant; $\mathrm{A}$ is the $\mathrm{p}-\mathrm{n}$ junction ideality factor; $\mathrm{T}$ is the cell temperature $(\mathrm{K})$; Irs is the cell reverse saturation current. The factor A determines the cell deviation from the ideal p-n junction characteristics; it ranges from 1 to 5 .

The cell reverse saturation current Irs varies with temperature according to the following equation:

$$
I_{r s}=I_{r r}\left(\frac{T}{T_{r}}\right)^{3} \exp \left(\frac{q E_{G}}{K A}\left[\frac{1}{T_{r}}-\frac{1}{T}\right]\right)
$$

where $T_{r}$ is the cell reference temperature, $I_{r r}$ is the cell reverse saturation temperature at $T_{r}$ and $E_{G}$ is the band gap of the semiconductor used in the cell.

The temperature dependence of the energy gap of the semiconductor is given by

$$
E_{G}=E_{G}(0)-\frac{\alpha T^{2}}{\beta+T}
$$

The photo current Iph depends on the solar radiation and cell temperature as follows:

$$
I_{p h}=\left[I_{s c r}+K_{i}\left(T-T_{r}\right)\right] \frac{S}{100}
$$

where Iscr is the cell short-circuit current at reference temperature and radiation, $\mathrm{Ki}$ is the short circuit current temperature coefficient, and $\mathrm{S}$ is the solar radiation in $\mathrm{mW} / \mathrm{cm} 2$

Based on these estimated values of parameters, the solar PV array of required size is designed.

\section{B. Design of SEPIC Converter -}

When the optimum operating point is reached, the voltage of the solar PV array, $\mathrm{v}_{\mathrm{pv}}=\mathrm{V}_{\mathrm{mpp}}=114.4 \mathrm{~V}$ and the current of the solar PV array, $\mathrm{i}_{\mathrm{pv}}=\mathrm{I}_{\mathrm{mpp}}=23.86 \mathrm{~A}$. Same current flows through the input inductor of the SEPIC, therefore, the current flowing through the input inductor is as,

$\mathrm{i}_{\mathrm{L} 1}=\mathrm{i}_{\mathrm{pv}}=23.86 \mathrm{~A}$.

The SEPIC converter is a switching converter that operates by periodically opening and closing an electronic switching by which output DC voltage either larger or smaller than its input DC voltage with no polarity reversal, meanwhile power must be conserved, the output current is lower than the source current. In order to convert voltage from one level to other this converter exchanges the energy between inductor and capacitor. The design of various components of SEPIC such as an input inductor, $\mathrm{L}_{1}$; an output inductor, $\mathrm{L}_{2}$; an intermediate capacitor, $\mathrm{C}_{1}$ and a DC link capacitor, $\mathrm{C}_{2}$ are summarized, where $f_{s w}$ is the switching frequency of the switch of SEPIC; $\mathrm{I}_{\mathrm{L} 1}$ is an average current flowing through the input inductor; $\Delta \mathrm{I}_{\mathrm{L} 1}$ is an amount of ripple allowed in iL1; $\Delta \mathrm{I}_{\mathrm{dc}}$ is an amount of ripple allowed in the DC link current; $\mathrm{I}_{\mathrm{L} 2}$ is an average current flowing through the output inductor; $\Delta \mathrm{I}_{\mathrm{L} 2}$ is the ripple allowed in the current flowing through the output inductor; $\Delta \mathrm{V}_{\mathrm{C} 1}$ is the ripple allowed in the voltage across the intermediate capacitor; $\Delta \mathrm{V}_{\mathrm{dc}}$ is the ripple allowed in the voltage across the DC link of VSI; $\omega$ h and $\omega$ l are the highest and lowest values of VSI output voltage frequencies, respectively in $\mathrm{rad} / \mathrm{sec}$; $\mathrm{f}$ is the frequency of VSI output voltage in $\mathrm{Hz} ; \mathrm{C}_{\mathrm{h}}$ and $\mathrm{C}_{\mathrm{l}}$ are the values of capacitors estimated corresponding to $\omega_{\mathrm{h}}$ and $\omega_{\mathrm{l}}$ respectively; $\mathrm{P}$ is the number of poles in the PMSM motor; $\mathrm{N}_{\text {rated }}$ is the rated speed of the motor; $\mathrm{N}$ is the minimum speed required to pump the water.

The switch $S_{1}$ controlled the amount of energy exchanged which is typically a transistor such as a MOSFET having much higher input impedance and lower voltage and do not require biasing resistors because switching is controlled by differences in voltage rather than a current. When the pulse is high the MOSFET Switch is on, input voltage charged the 
inductor $\mathrm{L}_{1}$ and capacitor $\mathrm{C}_{1}$ charged the inductor $\mathrm{L}_{2}$. The output is maintained by capacitor $\mathrm{C}_{2}$ when the diode is off. When the pulse is low the MOSFET is off, the capacitors are charged and the inductors output through the diode to the load. The output will be larger if the larger percentage of duty cycle the pulse is low. This is because the longer the inductors charge, the larger their voltage will be. However, the converter will fail, if the pulse lasts too long and the capacitors will not be able to charge. From figure, when the switch is closed, the diode is off.

$$
-\mathrm{V}_{\mathrm{S}}+\mathrm{V}_{\mathrm{L} 1}+\mathrm{V}_{\mathrm{C} 1}-\mathrm{V}_{\mathrm{L} 2}=0
$$

Average voltage, $\mathrm{VC} 1=\mathrm{VS}$, then $\mathrm{VL} 1=\mathrm{VS}$

When the switch is open, the diode is on,

$$
-V_{S}+V_{L 1}+V_{C 1}-V_{O}=0
$$

Since, $\mathrm{V}_{\mathrm{C} 1}=\mathrm{V}_{\mathrm{S}}$ then $\mathrm{V}_{\mathrm{L} 1}=-\mathrm{V}_{\mathrm{O}}$

According to the volt-secs

$$
\mathrm{V}_{\mathrm{S}} \times \mathrm{T}_{\mathrm{ON}}=\left(\mathrm{V}_{\mathrm{C}}-\mathrm{V}_{\mathrm{O}}-\mathrm{V}_{\mathrm{S}}\right) \times \mathrm{T}_{\mathrm{OFF}}
$$

For the output inductor,

$$
\mathrm{V}_{\mathrm{C}} \times \mathrm{T}_{\mathrm{ON}}=\mathrm{V}_{\mathrm{O}} \times \mathrm{T}_{\mathrm{OFF}}
$$

From above equation

$$
\mathrm{V}_{\mathrm{S}} \times \mathrm{D} \times \mathrm{T}=\mathrm{V}_{\mathrm{O}} \times(1-\mathrm{D}) \times \mathrm{T}
$$

Now, assuming no switching loss inside converter,

$$
\mathrm{P}_{\mathrm{IN}}=\mathrm{P}_{\mathrm{OUT}}=\mathrm{V}_{\mathrm{S}} \times \mathrm{I}_{\mathrm{S}}=\mathrm{V}_{\mathrm{S}} \times \mathrm{I}_{\mathrm{L} 1}
$$

Output power, $\mathrm{P}_{\text {OUT }}=\mathrm{V}_{\mathrm{O}} \times \mathrm{I}_{\mathrm{O}}$

Average inductor current and average source Current,

$$
\mathrm{I}_{\mathrm{L} 1}=\mathrm{I}_{\mathrm{S}}=\left(\mathrm{V}_{\mathrm{O}} \times \mathrm{I}_{\mathrm{O}}\right) / \mathrm{R}=\left(\mathrm{V}_{\mathrm{C} 2}\right) / \mathrm{R}
$$

The $\mathrm{I}_{\mathrm{L} 1}$ and $\mathrm{I}_{\mathrm{L} 2}$, when the switch is closed,

$$
\begin{aligned}
\mathrm{V}_{\mathrm{L} 1}=\mathrm{V}_{\mathrm{S}} & =\mathrm{L}_{1} \times\left(\mathrm{di}_{\mathrm{L} 1} / \mathrm{dt}\right) \\
& =\mathrm{L}_{1} \times\left(\Delta \mathrm{I}_{\mathrm{L} 1} / \Delta \mathrm{t}\right) \\
& =\mathrm{L}_{1} \times\left(\Delta \mathrm{I}_{\mathrm{L} 1} / \mathrm{D} \times \mathrm{T}\right)
\end{aligned}
$$

Then,

$$
\Delta \mathrm{I}_{\mathrm{L} 1}=\left(\mathrm{V}_{\mathrm{S}} \times \mathrm{D} \times \mathrm{T}\right) / \mathrm{L}_{1}=\left(\mathrm{V}_{\mathrm{S}} \times \mathrm{D}\right) / \mathrm{L}_{1} \times \mathrm{f}
$$

Similarly,

$$
\begin{aligned}
\mathrm{V}_{\mathrm{L} 2} & =\mathrm{V}_{\mathrm{C} 1}=\mathrm{V}_{\mathrm{S}} \\
& =\mathrm{L}_{2}\left(\mathrm{di}_{\mathrm{L} 2} / \mathrm{dt}\right) \\
& =\mathrm{L}_{2}\left(\Delta \mathrm{I}_{\mathrm{L} 2} / \Delta \mathrm{t}\right) \\
& =\mathrm{L}_{2}\left(\Delta \mathrm{I}_{\mathrm{L} 2} / \mathrm{D} \times \mathrm{T}\right)
\end{aligned}
$$

Then,

$$
\Delta \mathrm{I}_{\mathrm{L} 2}=\left(\mathrm{V}_{\mathrm{S}} \times \mathrm{D} \times \mathrm{T}\right) / \mathrm{L}_{2}=\left(\mathrm{V}_{\mathrm{S}} \times \mathrm{D}\right) / \mathrm{L}_{2} \times \mathrm{f}
$$

The output ripple voltage is,

$\Delta \mathrm{V}_{\mathrm{C} 2}=\Delta \mathrm{V}_{\mathrm{O}}=\left(\mathrm{V}_{\mathrm{O}} \times \mathrm{D}\right) / \mathrm{R} \times \mathrm{C}_{2} \times \mathrm{f}$

$$
\begin{aligned}
L_{1} & =\frac{D * V_{P V}}{f_{S W^{*}} * I_{L 1}} \\
& =(0.53 * 114.4) / 20 * 103 * 2.386 \\
& =1.27 \mathrm{mH}
\end{aligned}
$$

$$
L_{2}=\frac{(1-D) * V_{P V}}{f_{S W^{*}} * I_{L 1}}
$$

$$
=1.46 \mathrm{mH}
$$

$$
\begin{aligned}
C_{1} & =\frac{D * I_{P V}}{f_{S W^{*} \Delta V_{C 1}}} \\
& =42.77 \mu \mathrm{F}
\end{aligned}
$$

Table -1 Values of Designed Parameter

\begin{tabular}{|c|c|c|}
\hline Parameter & Designed Value & Selected Value \\
\hline L1 & $1.27 \mathrm{mH}$ & $1.3 \mathrm{mH}$ \\
\hline $\mathrm{L} 2$ & $1.46 \mathrm{mH}$ & $1.5 \mathrm{mH}$ \\
\hline $\mathrm{C} 1$ & $42.77 \mu \mathrm{F}$ & $43 \mu \mathrm{F}$ \\
\hline
\end{tabular}

\section{CONTROL STRATERGY}

\section{A. MPPT -}

In the proposed topology, MPPT is achieved using an INC method. The advantage of theoretically no steady state oscillation and fast dynamic response make it quite effective for SWP. Figure shows the algorithm for INC MPPT method. For a good steady state and dynamic performance, a proper value of step size needs to be selected. The step size chosen for this work is 0.001 .

In the incremental conductance method, the controller measures incremental changes in array current and voltage to predict the effect of a voltage change. This method requires more computation in the controller, but can track changing conditions more rapidly than perturb and observe method (P\&O). Like the P\&O algorithm, it can produce oscillations in power output [16]. This method utilizes the incremental conductance $(\mathrm{dI} / \mathrm{dV})$ of the photovoltaic array to compute the sign of the change in power with respect to voltage $(\mathrm{dP} / \mathrm{dV})$. 
The incremental conductance method computes the maximum power point by comparison of the incremental conductance $(\mathrm{I} \Delta / \mathrm{V} \Delta)$ to the array conductance $(\mathrm{I} / \mathrm{V})$. When these two are the same $(\mathrm{I} / \mathrm{V}=\mathrm{I} \Delta / \mathrm{V} \Delta)$, the output voltage is the MPP voltage. The controller maintains this voltage until the irradiation changes and the process is repeated.

The disadvantage of perturb and observe method to track the peak power under fast varying atmospheric condition is overcome by IC method. The IC can determine that the MPPT has reached the MPP and stop perturbing the operating point. If this condition is not met, the direction in which the MPPT operating point must be perturbed can be calculated using the relationship between $\mathrm{dl} / \mathrm{dV}$ and $-\mathrm{I} / \mathrm{V}$ This relationship is derived from the fact that $\mathrm{dP} / \mathrm{dV}$ is negative when the MPPT is to the right of the MPP and positive when it is to the left of the MPP. This algorithm has advantages over $\mathrm{P} \& \mathrm{O}$ in that it can determine when the MPPT has reached the MPP, where P\&O oscillates around the MPP. Also, incremental conductance can track rapidly increasing and decreasing irradiance conditions with higher accuracy than $\mathrm{P} \& \mathrm{O}$.

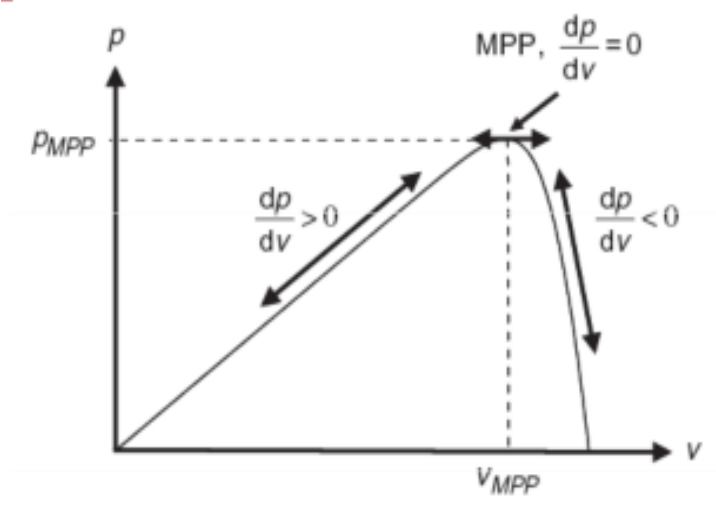

Fig. 7. Incremental Conductance MPPT method

Figure shows that the slope of the P-V array power curve is zero at The MPP, increasing on the left of the MPP and decreasing on the Right hand side of the MPP. The basic equations of this method are as follows.

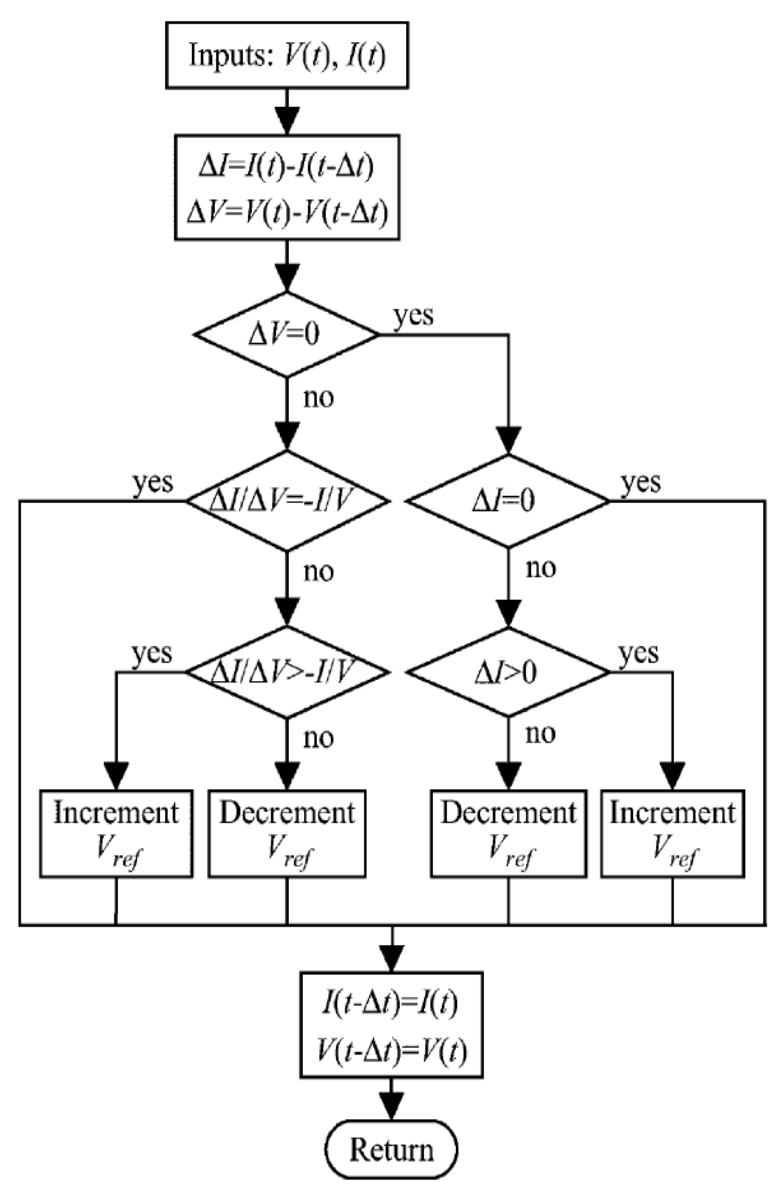

Fig. 8. Flowchart of Incremental Conductance MPPT algorithm

In the voltage source region,

$$
\begin{gathered}
\frac{\delta I_{P V}}{\delta V_{P V}}>-\frac{I_{P V}}{V_{P V}} \rightarrow d \\
=+\Delta d\left(\text { i. }_{x},\right. \text { increment duty cycle) }
\end{gathered}
$$

In the current source region,

$$
\begin{aligned}
& \frac{\delta I_{P V}}{\delta V_{P V}}<-\frac{I_{P V}}{V_{P V}} \rightarrow d \\
& =d-\Delta d(\text { i.e., decrement duty cycle) }
\end{aligned}
$$

At MPP,

$$
\frac{\delta I_{P V}}{\delta V_{P V}}=-\frac{I_{P V}}{V_{P V}} \rightarrow \operatorname{dor} \Delta d
$$




\section{B. Speed Control of PMSM -}

In the proposed topology, the speed control is achieved using vector control. After the generation of $\omega$ e mod, it is fed to the speed controller. The speed controller output is considered as reference quadrature axis current $\left(\mathrm{Iq}^{*}\right)$. The speed controller reduces $\omega$ e mod to zero by adjusting the Iq*. Iq* is given as,

$$
\mathrm{Iq} *(\mathrm{k})=\mathrm{Iq} *(\mathrm{k}-1)+\mathrm{Kp} \omega\{\omega \mathrm{e} \bmod (\mathrm{k})-\omega \mathrm{e} \bmod (\mathrm{k}-1)\}+
$$
Ki $\omega$ we $\bmod (\mathrm{k})$

Where, Kp $\omega$ and Ki $\omega$ are proportional and integral constants respectively used in speed controller. Since for SWP, there is no need to control the speed over base speed. Hence no field weakening is required. Therefore, Id* is kept zero. Using an inverse Park's transform ( $\mathrm{dq} 0$ to $\mathrm{abc})$, the reference stator currents of PMSM (ia*, $\mathrm{ib}^{*}$ and $\left.\mathrm{ic}^{*}\right)$ are computed from $\mathrm{Id}^{*}$ and Iq*. The sensed motor phase currents ia, ib and ic and the reference currents $\mathrm{ia}^{*}$, $\mathrm{ib}^{*}$ and $\mathrm{ic}^{*}$ are fed to hysteresis controller, which generates gating signals for VSI.

Table -2 Specifications of PMSM

\begin{tabular}{|l|l|}
\hline Parameter & Value \\
\hline Power & $2.4 \mathrm{KW}$ \\
\hline Rated Torque & $10 \mathrm{Nm}$ \\
\hline DC Link voltage & $350 \mathrm{~V}$ \\
\hline Speed & $2300 \mathrm{rpm}$ \\
\hline No. of Phases & 3 \\
\hline No. of Poles & 8 \\
\hline Stator winding resistance & $0.4578 \Omega / \mathrm{ph}$ \\
\hline Armature winding inductance & $0.0034 \mathrm{H}$ \\
\hline Flux linkage & $0.171 \mathrm{~Wb} / \mathrm{m} 2$ \\
\hline
\end{tabular}

\section{SimUlation AND Results}

The proposed system is simulated and verified the outputs for a resistive load. The solar energy is extracted using SEPIC converter, which leads to inverter and then PMSM motor, the single stage operations are simulated separately and obtain the overall system response.

Fig. 9. SEPIC Converter

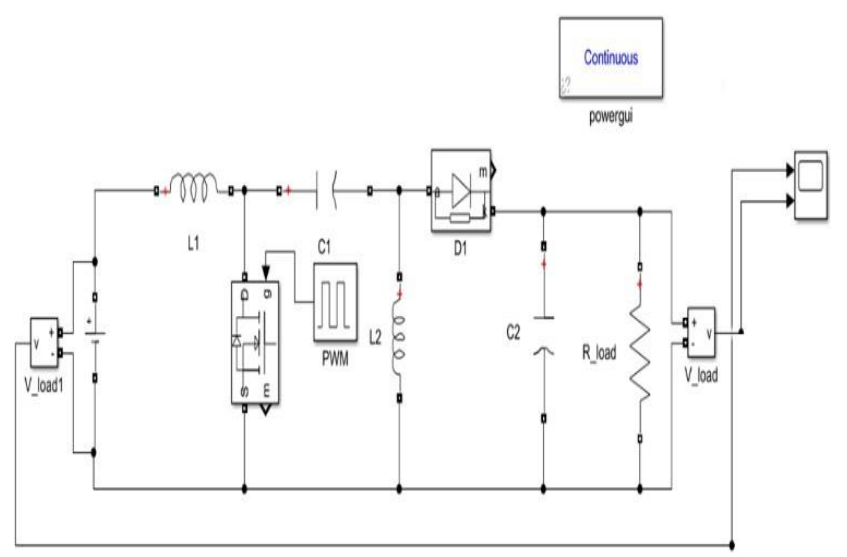

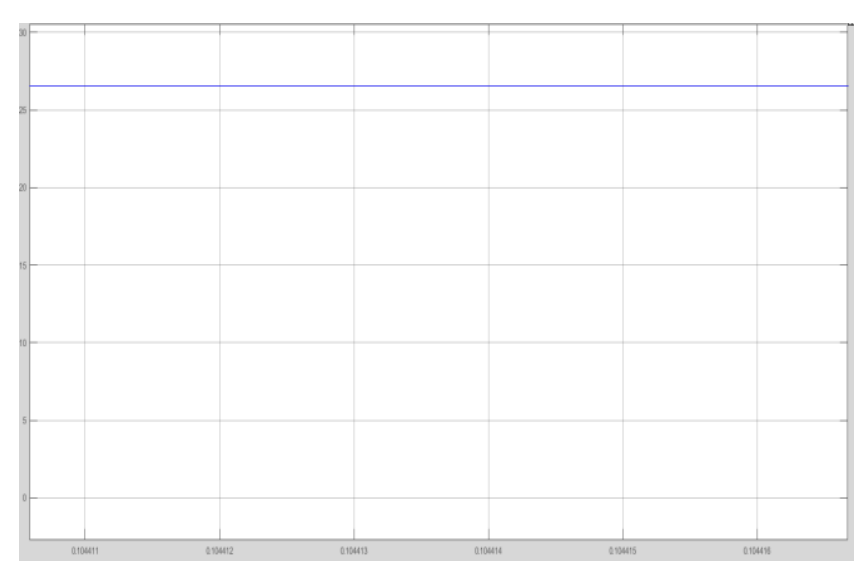

Fig. 10. Output from PV Module

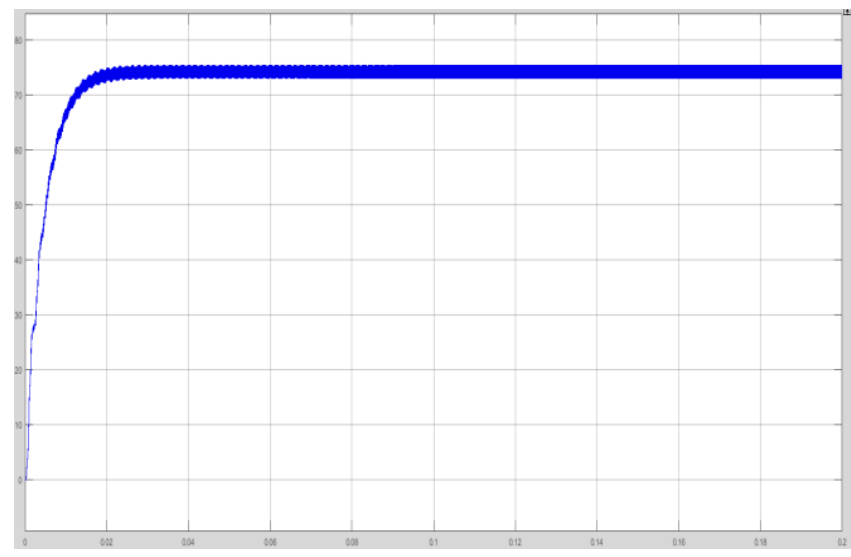

Fig. 11. Output from SEPIC Converter

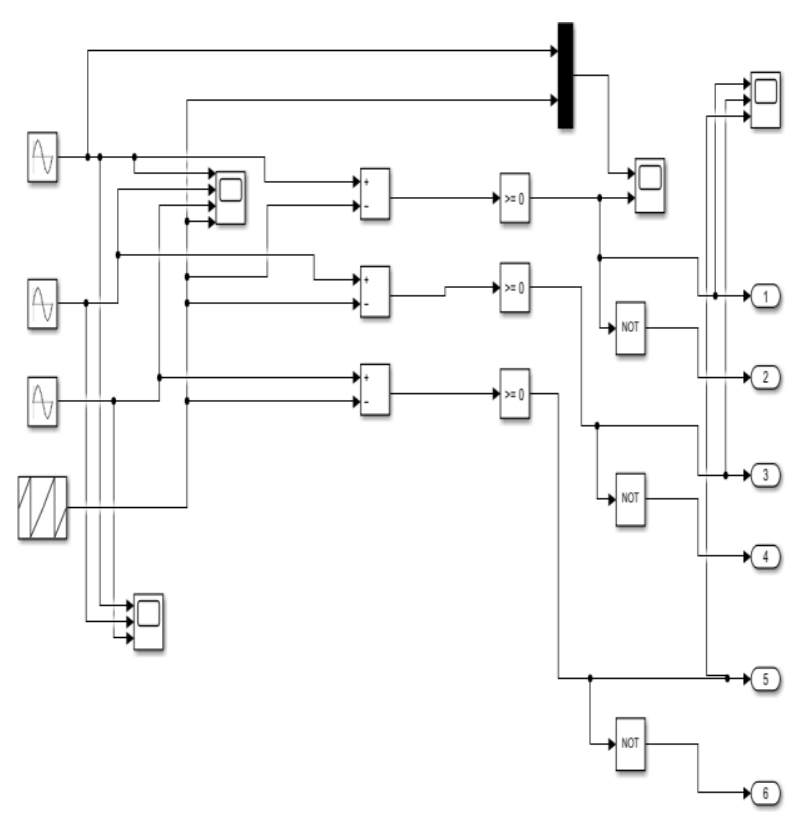


International Journal of Engineering Applied Sciences and Technology, 2020

Vol. 4, Issue 9, ISSN No. 2455-2143, Pages 138-148

Published Online January 2020 in IJEAST (http://www.ijeast.com)

Fig. 12. PWM for Inverter

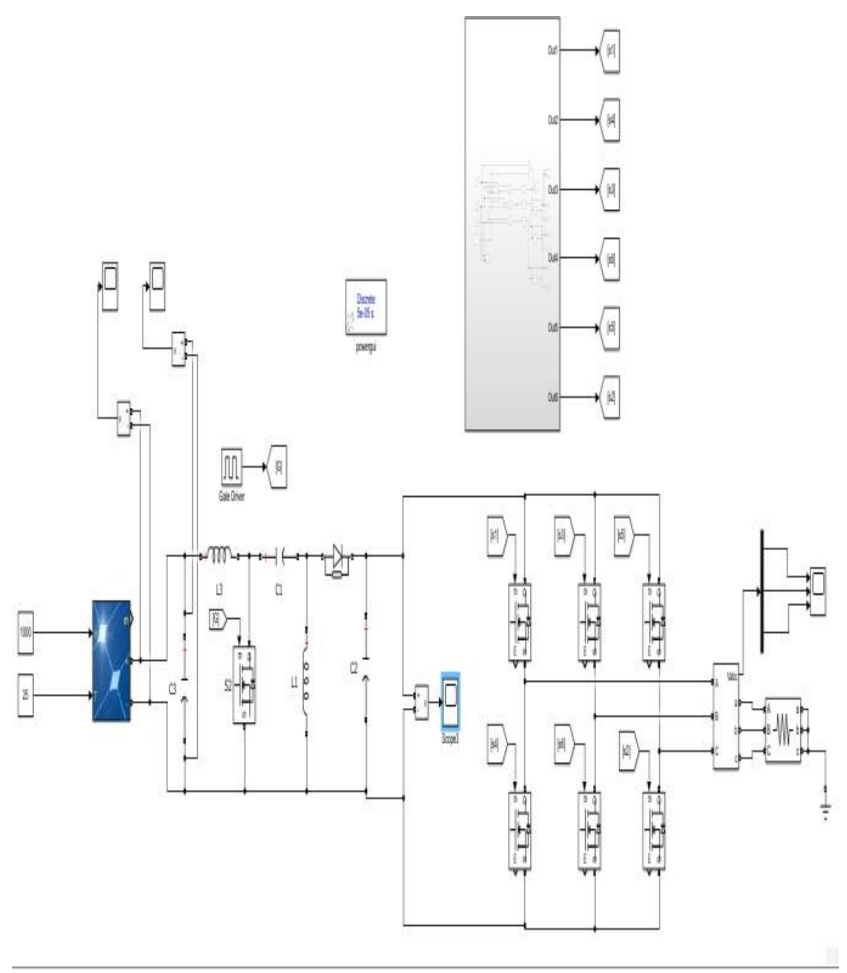

Fig. 13. Simulation for proposed system

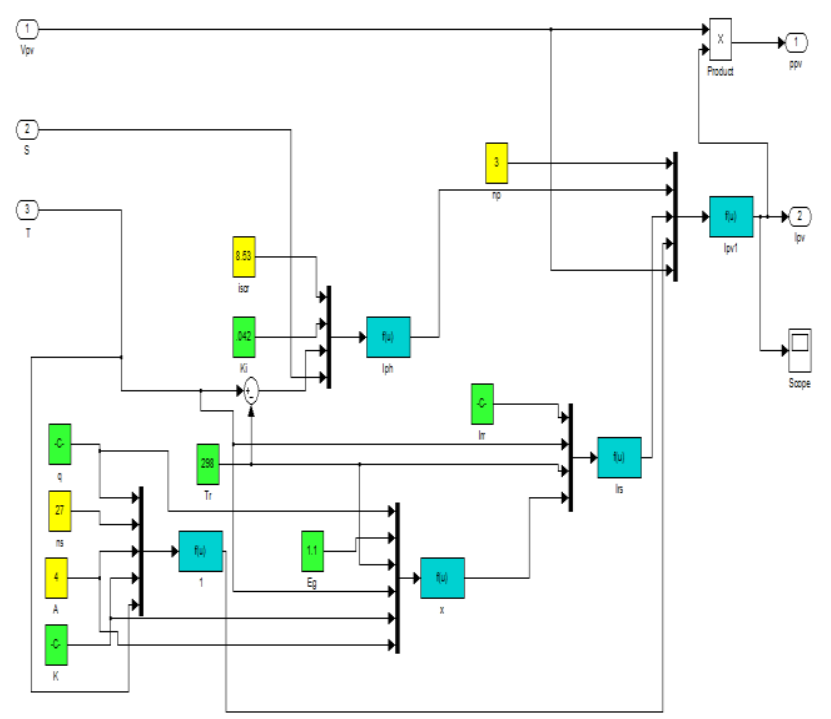

Fig. 14. Simulink model for PV cell

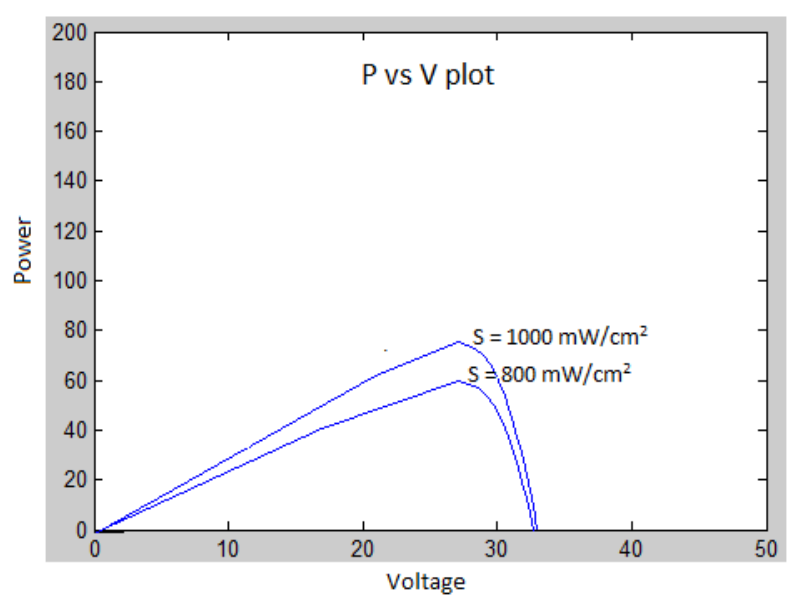

Fig. 15. P-V curve of the PV array

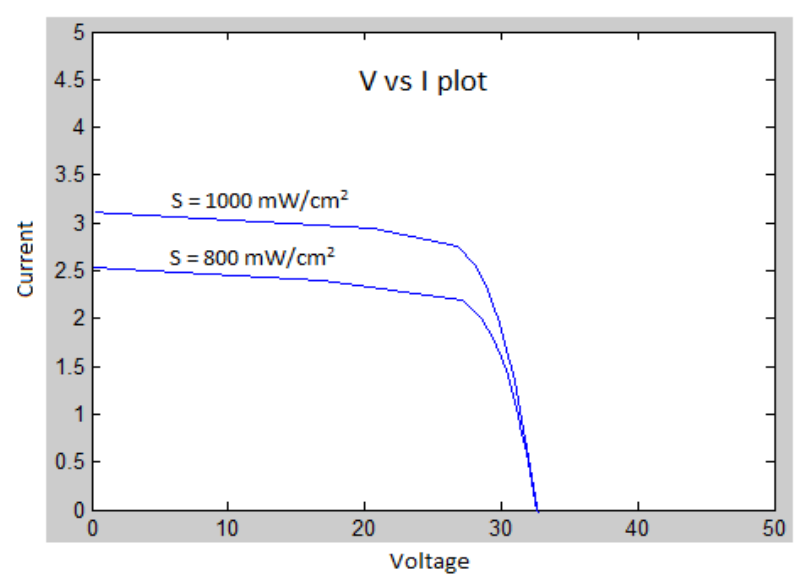

Fig. 16. I-V curve of PV array 


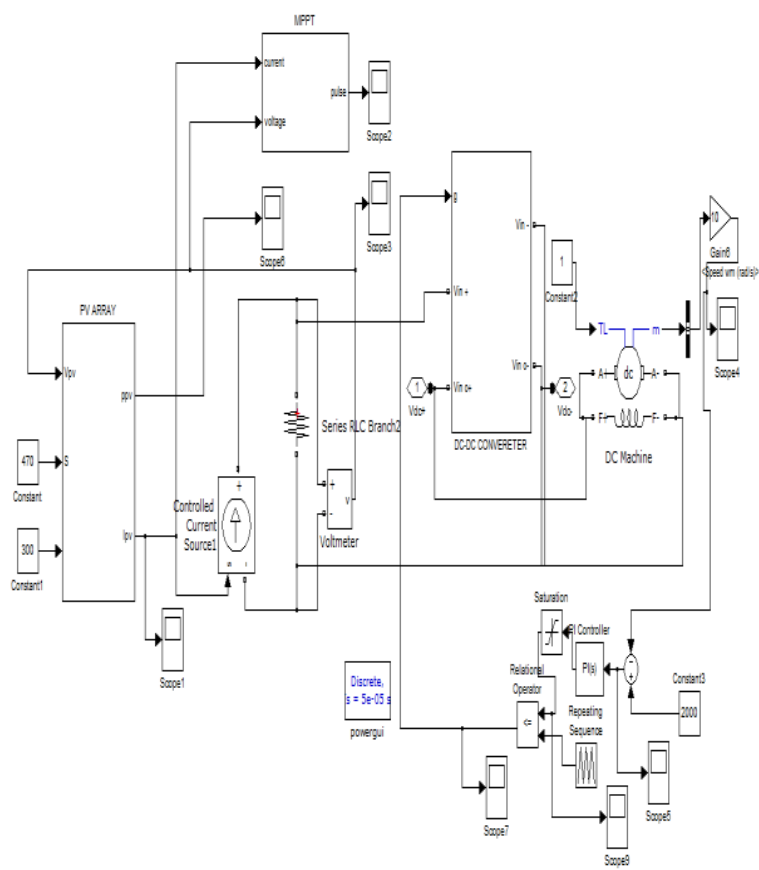

Fig. 17. Simulink model of PV system with MPPT

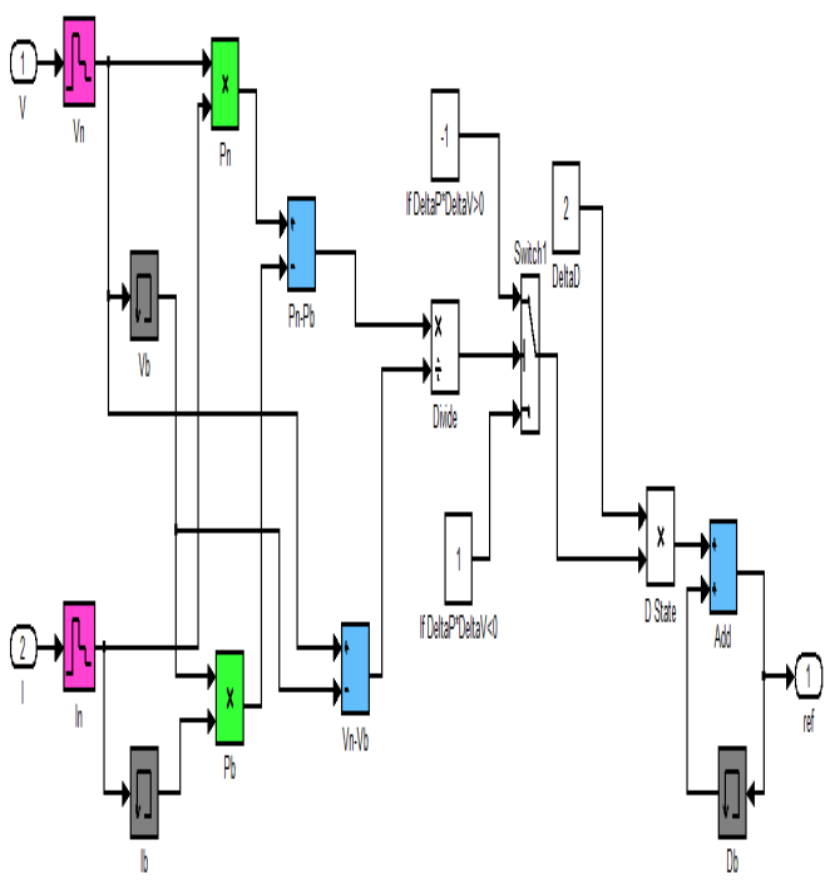

Fig. 18. Simulink model for implementation of incremental conductance algorithm
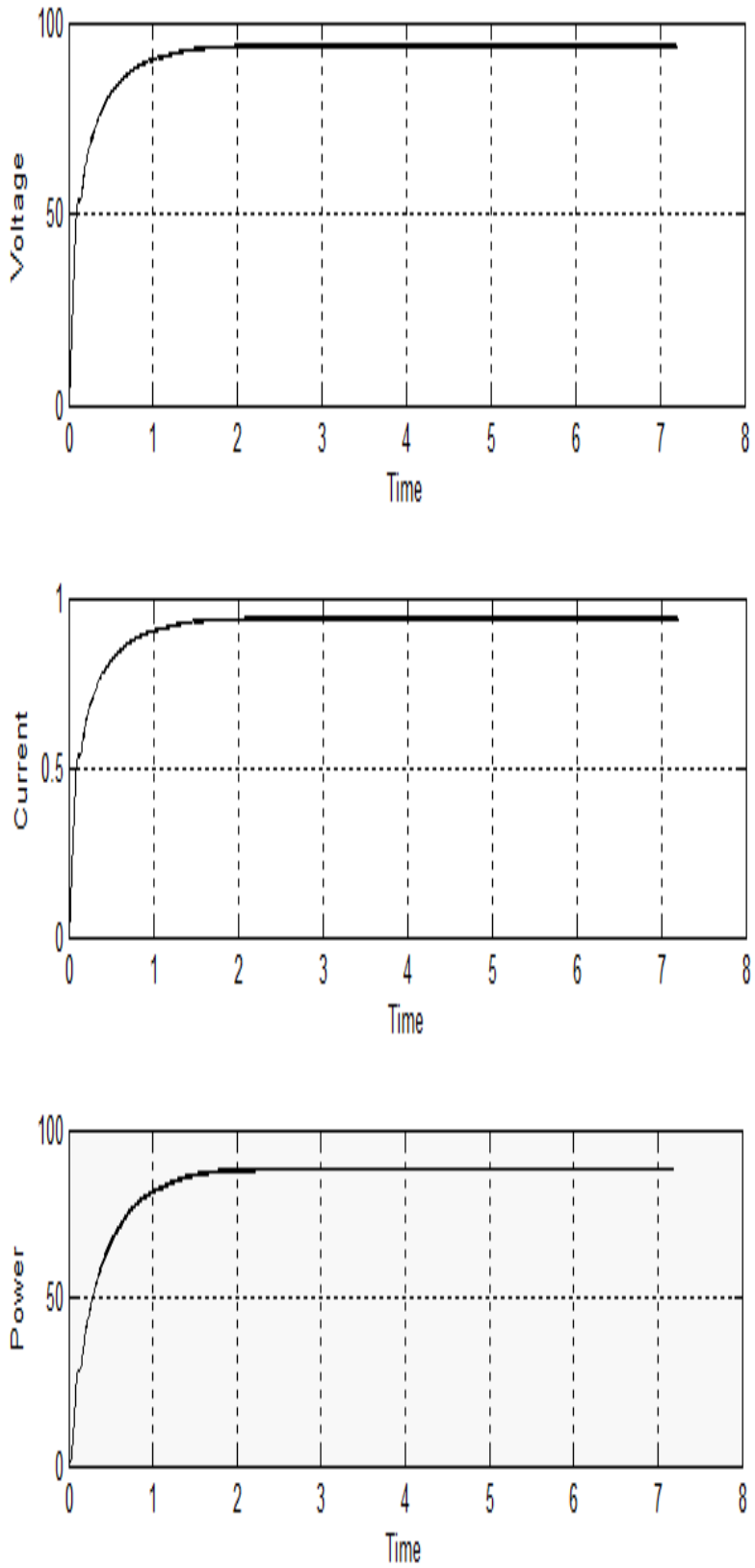

Fig. 19. Output waveforms of MPPT

\section{CONCLUSION}

The Design and implementation of solar PV fed PMSM driven water-pumping system validated. MATLAB/Simulink used for the simulation of the system. The variation of various system parameters has been studied during starting and steady state at STC and under wide range of insolation change. The system have successful operation even at 20\% solar irradiance. The use of PMSM has improved 
International Journal of Engineering Applied Sciences and Technology, 2020

Vol. 4, Issue 9, ISSN No. 2455-2143, Pages 138-148

Published Online January 2020 in IJEAST (http://www.ijeast.com)

the efficiency of the system. Hence, the proposed system gives a fast, efficient and reliable solution for SWP.

\section{REFERENCE}

[1] G.M Masters (2013) "Renewable and efficient electric power systems" (IEEE Press, Wiley and Sons, Inc., Hoboken, New Jersey), pp. 445-452.

[2] R. Foster, M. Ghassemi, M. Cota (2010) "Solar energy: renewable energy and the environment" CRC Press, Taylor and Francis Group, Inc., Boca Raton, Florida.

[3] S. Parvathy, A. Vivek (2015) "A photovoltaic water pumping system with high efficiency and high lifetime". Int. Conf. Advancements in Power and Energy (TAP Energy), Kollam, India, 24-26 June, pp. 489493.

[4] V.C Sontake, V.R Kalamkar (2016) "Solar photovoltaic water pumping system - a comprehensive review", Renew. Sustain. Energy Rev, 59, pp. $1038-1067$.

[5] M.G Villalva, J.R Gazoli, E.R Filho (2009) “Comprehensive approach to modeling and simulation of photovoltaic arrays", IEEE Trans. Power Electron., 24, (5), pp. 1198-1208.

[6] S. Chowdhury, G.A Taylor, S.P Chowdhury et al. (2007) "Modelling, simulation and performance analysis of a PV array in an embedded environment". Proc. 42nd Int. Universities Power Engineering Conf. (UPEC), Brighton,UK, pp. 781-785.

[7] B. Singh, R. Kumar (2016) "Simple brushless DC motor drive for solar photovoltaic array fed water pumping system", IET Power Electron.,9, (7), pp. 1487-1495

[8] S. Jain, R. Karampuri, V.T Somasekhar (2016) “An integrated control algorithm for a single- stage PV pumping system using an open-end winding induction motor", IEEE Trans. Ind.Electron., 63, (2), pp. 956965

[9] R. Kumar, B. Singh (2017) "Single stage solar PV fed brushless DC motor driven water pump", IEEE J. Emerg. Sel. Top. Power Electron., 5, (3), pp. 1377-1385

[10] V. Narayana, A.K Mishra, B. Singh (2017) "Development of low-cost PV arrayfed SRM drive-based water pumping system utilizing CSC converter", IET Power Electron., 10, (2), pp. 156-168

[11] D.P Marcetic, E.M Adzic (2010) "Improved three-phase current reconstruction for induction motor drives with DC-link shunt", IEEE Trans. Ind. Electron., 57, (7), pp. 2454-2462

[12] D. Casadei, F. Profumo, G. Serra et al. (2002) "FOC and DTC: two viable schemes for induction motors torque control", IEEE Trans. Power Electron., 17, (5), pp. 779-787
[13] R.V Nemade, J.K Pandit, M.V Aware (2017) "Reconfiguration of Ttype inverter for direct torque controlled induction motor drives under open-switch faults", IEEE Trans. Ind. Appl., 53, (3), pp. 2936-29.

[14] X. Weidong, And W.G.Dunford (2004) "A Modified Adaptive Hill Climbing MPPT Method for Photovoltaic Power Systems", IEEE $35^{\text {th }}$ Annual Power Electronics Specialists Conf., p. 1957. 